\title{
The Significance of Validity Theory to College English Listening and Speaking Course Test
}

\author{
Dan LIU * \\ School of Public English Teaching and Research, Harbin Normal University, Harbin 150025, China \\ liudan309@126.com \\ * Corresponding author
}

Keywords: Validity, Listening, Speaking, Test

\begin{abstract}
The validity theory is an effective criterion to measure the success of a test, playing an important role in College English Listening and Speaking Course. Tests for College English Listening and Speaking Course under the validity theory are more reasonable, scientific and efficient when the College English teachers structure tests in their minds. The test for College English Listening and Speaking Course were taken as an example to explain the significance of the validity theory to improve the quality of the test. On the basis of the statistical data, the characteristics of the test were found out and analyzed. Several effective ways to improve the listening and speaking competence were also discussed in this paper.
\end{abstract}

\section{Introduction}

The validity can show itself after the test based on real data. Only when the test is real and reflect the characteristic of the test, can we consider it as the most effective measure [1]. Validity is in fact a kind of measure degree between the result of a test and the psychological characteristics of the testees that the test-maker wants to get.

These years, the listening and speaking course plays a more and more important role in College English programs in China. How to make a criterion for college listening and speaking course becomes an intractable issue. Unlike other courses, listening and speaking test aims not mainly at students vocabulary, grammar, reading, writing, listening or speaking as only one aspect, but the students' reaction, understanding and competence of expressing themselves [2]. Of course, during listening and speaking test, the vocabulary the students' use, grammar correction, background knowledge accumulated by reading and writing, all the factors have an effect on the final result. Thus, the test-makers (the teachers) should at first set the goal of test: what do they want to get is a very important thing. After the test, the test-makers have to find out the way to deal with all the problems revealed from the test and set further teaching plan to improve the students listening and speaking competence.

In this paper, the test for the College English Listening and Speaking Course were taken as an example to explain the significance of the validity theory. The statistical data in the test were analyzed and the characteristics of the test were found out. Several effective ways to improve the listening and speaking competence were also discussed.

\section{Test and Analysis}

College English oral test firstly began in China at the end of 20th century. The design principle is based on communication information in reality that is, providing real scenes, creating mock communication environments and at the same time embodying communication mutuality [3].Usually, the students' oral competence is tested in mock communication environment, involving the students competence in listening and speaking.

The mock communication environment tests the listening and speaking competence from every aspect, as illustrated by the following test. The content of the test is about some common topics in 
daily life on campus or in society, such as in the classroom, in the library, in the stadium, on the street, in the shop, and also in online voice chat. Two hundred of undergraduates from the ordinary classes took part in the test. It is aimed to examine their English listening and speaking competence from five aspects: understanding of teacher's questions, content of speech, the ability of language expression, grammar correctness and English intonation, as shown in figure 1. The weight ratio of each aspect in the test is shown in Fig.1.

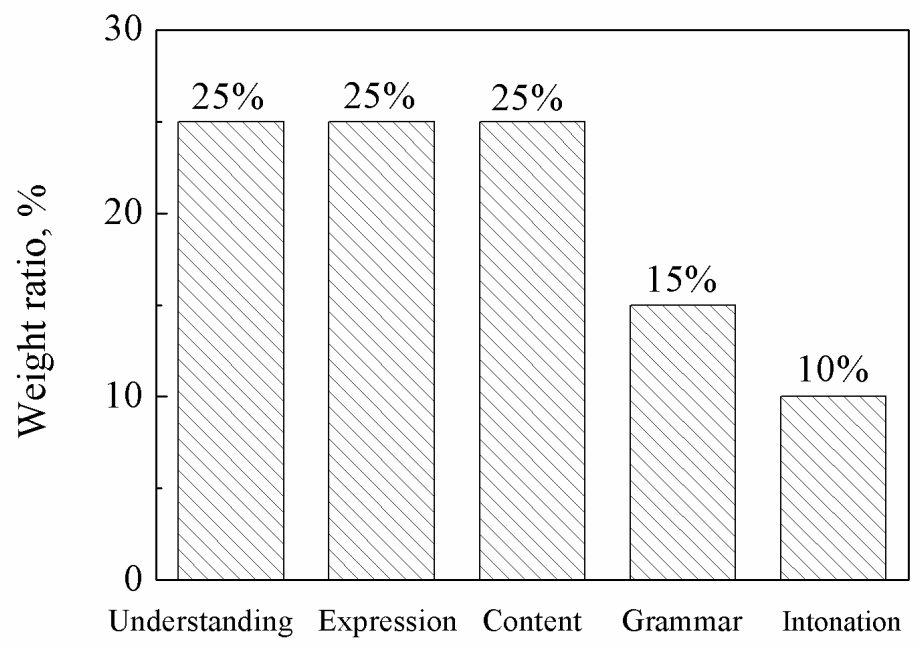

Fig. 1 Weight ratio of each criterion in the test

We get the final grades of the students by plus of the results from the five aspects. Fig. 2 shows the distribution of the final grade. As shown in this figure, the whole trend of the test shows that the large proportion of students' listening and speaking competence is in the middle level, indicating a better condition of listening and speaking competence than the old "dumb English" age in China many years ago.

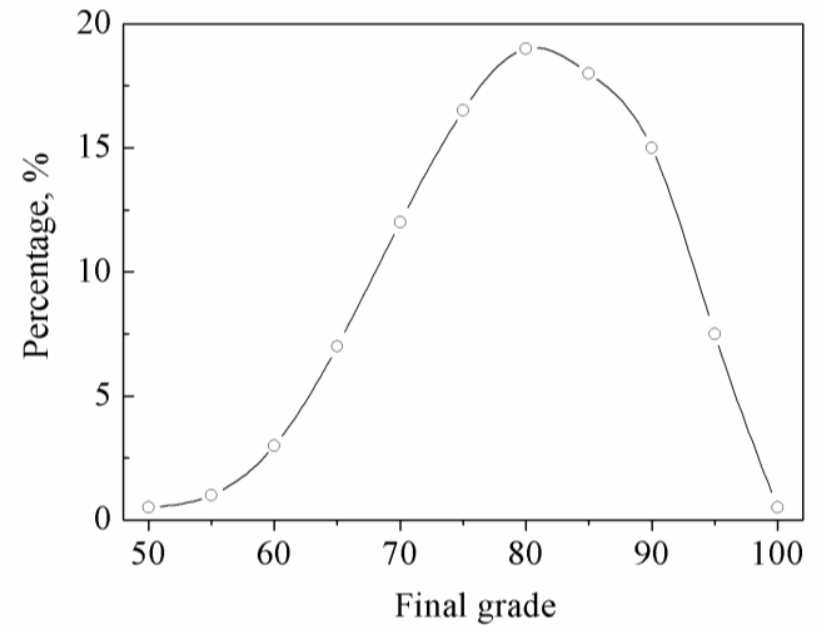

Fig. 2 Grade distribution of the test

On the basis of the validity theory, a brief summary of the test final grade is obtained and shown in table 1. The highest and lowest grade of the test is 100 (only one student) and 53(also one student), respectively, with an average grade of 81.75 . The median grade is 82 , suggesting $50 \%$ of the students, namely 100 students in the test, have a grade higher than 82 . It is an indication of reasonable result in the test, which is also consistent with the analysis in Fig. 2. 
Table 1 Summary of Final Grade

\begin{tabular}{|c|c|c|c|}
\hline Highest & Lowest & Average & Median \\
\hline 100 & 53 & 81.75 & 82 \\
\hline
\end{tabular}

\section{Problems Revealed from the test}

Some problems are revealed according to test.

Most of the students understand the comparatively easy question, but when there are some complicated ones, they feel a bit puzzled. For some students, listening comprehension is just a kind of form of test. When listening concerned with communication environment, it is different. Therefore, facing with the teacher's questions, some students cannot understand correctly or only say "sorry" for the first time.

For the second aspect in the test, expression, we should say that it's an integrated process from the students' vocabulary to their courage. From the result of the test, some students who are very shy or introverted get low grades in this item. So the validity analysis also reveals some psychological problems.

For the third aspect, content, some students seem to have little to say, although they know a lot about the topic [4]. Even for the topics they are very familiar with, like reading in the library or exercising in the gym, they cannot speak too much. In the test, only about one third of the students give a comparatively abundant content in their speech.

Almost all the students have solid ground in grammar after about seven years of training in grammar in their middle school age. They interweave a kind of hatred in this advantage, because most of them think grammar is boring but indispensable in English learning. The disadvantage is that before students open their mouths, the first thing into their minds is grammar, which disturbs their language sense.

As for intonation, most students consider the rise and fall of the voice in speaking is pleasing to the ear, but not recognize its importance when communicating with others. They have not realized that a sentence conveying a good meaning of praise, can have the opposite meaning if the intonation is misused. From the validity analysis, we can infer that the students are too busy remembering the new words, learning grammar, going over for the written examinations to put a little emphasis on this seemingly unimportant item.

\section{Tactics to improve listening and speaking competence}

Under the guidance of validity theory, it is possible for the test-makers to design more meaningful tests. The test in this paper is conducted to test the student's competence of listening and speaking in English. Behind the test, there's a question for the teacher: why the students appear competent or not and what is the most important thing for the educator to acquire to adjust the next step of teaching plans.

Cook has ever said that people learn speaking by listening [5]. In order to improve the student's competence of understanding in English, the teacher may ask as many as possible questions about listening materials, and then talk freely with the students about the topics involved. Gradually, it will be considered as a natural process for the students to listen, to understand, to think, and to speak.

For the competence of English expression, it will take time to improve it, because expression is an integrated process including vocabulary choice, background knowledge, logic, and even courage [6]. When the teachers make a teaching plan, maybe it is better for them to take as many aspects as possible into consideration. At the same time, reading and writing can improve students' background information, which will make them talkative when expressing themselves.

Many years solid ground in grammar turns disadvantaged at this stage, and at the same time limits the students' way of thinking. Because many students form the ideas in Chinese way at first, then 
translate them into English in their minds, at last say out in English. It takes them a long time to arrange language materials in mind into a grammatically logic sentence. According to the analysis result, the teacher may cultivate the students' language sense during the classroom teaching and help the students to set a good habit of thinking way in English.

Finally, as for the intonation, students should be encouraged to improve themselves by imitation. Providing some audio and video materials for the students is also a good method. All these combined methods can be used to improve the students' listening and speaking competence.

\section{Summary}

The validity theory helps to find out the characteristics of the test and the students' problems revealed in the test. A test for the College English Listening and Speaking Course was taken in this paper. The test result was summarized and analyzed using the validity method. The students' problems were discussed from the five English communication aspects: understanding, content, language expression, grammar and intonation. The classroom teaching tactics can be combined together to improve the students' listening and speaking competence.

\section{Acknowledgement}

This research was financially supported by the Heilongjiang Province "The Twelfth Five-Year Plan" Educational Science Foundation (Grant No. GBC1212041).

\section{References}

[1] G. Y. Huang, Educational Measure and Evaluation, East China Normal University Press, Shanghai, 2013.

[2] R. Titone, Teaching Foreign Languages: a Historical Sketch, Georgetown University Press, Washington D.C, 1968.

[3] S. Bax, The End of CLT: a Context Approach to Language Teaching, ELT Journal, 57 (2003) 278-287.

[4] K. Johnson, Language Teaching and Skill Learning, Blackwell, Oxford, 1996.

[5] V. Cook, Second Language Learning and Language Teaching, Foreign Language Teaching and Research Press, Beijing, 1996.

[6] R. B. Kaplan, R. B. Jr. Baldauf, Language and Language-in-Education Planning in the Pacific Basin, Kluwer Academic Publishers, Dordrecht, Netherlands, 2003. 